\title{
Urgences
}

\section{L'ange des ruptures}

\section{Claude Beausoleil}

Numéro 15, octobre 1986

Épigraphiques

URI : https://id.erudit.org/iderudit/025297ar

DOI : https://doi.org/10.7202/025297ar

Aller au sommaire du numéro

Éditeur(s)

Urgences

\section{ISSN}

0226-9554 (imprimé)

1927-3924 (numérique)

Découvrir la revue

Citer ce document

Beausoleil, C. (1986). L'ange des ruptures. Urgences, (15), 30-30.

https://doi.org/10.7202/025297ar

Ce document est protégé par la loi sur le droit d'auteur. L’utilisation des services d'Érudit (y compris la reproduction) est assujettie à sa politique d'utilisation que vous pouvez consulter en ligne.

https://apropos.erudit.org/fr/usagers/politique-dutilisation/
Cet article est diffusé et préservé par Érudit.

Érudit est un consortium interuniversitaire sans but lucratif composé de l’Université de Montréal, l'Université Laval et l'Université du Québec à Montréal. Il a pour mission la promotion et la valorisation de la recherche. https://www.erudit.org/fr/ 


\section{Claude Beausoleil \\ L'ANGE DES RUPTURES}

L'échelle humaine des choses prend tout son sens

sur la rue des Assassins.

Michaël Delisle: d'un texte en préparation

I Journal 15 avril 86

“... L'écriture se déplace. Vitesse douce des jours qui coulent sans le besoin d'images éblouies. La recherche a aussi ses accalmies magiques, lieux de retour vers le fondamental."

II Extrait d'un cahier de voyage 18 avril 86

j'ai retrouvé Venise où

elle m'avait laissé au

bord de la lagune où

dorment des palais

l'ange serait le signe des Temps

l'ange avance ses barques de Lumière

la brisure est une oscillation

la beauté est cet homme regardant l'horizon

ceci n'est pas une illusion

le paysage s'incline

décor retenu par les eaux d'une rue sans fin 